\title{
The Relation Between Knowledge, Attitude, and Behavior The Usage of Personal Protective Equipment With Accident at Work on Pt. X Project Apartment Bekasi Workers.
}

\author{
Milla Puspa Andini Alydrus \\ Master of Public Health, Universitas Muhammadiyah Jakarta \\ E-mail: mpuspaandini@gmail.com
}

\begin{abstract}
Based on the research, which conducted by Vondra Anggi Saputro about the application of PPE (personal protective equipment) with an accident at work in 2015 in the Metal Casting Production Work Unit found that there is a significant relation between acknowledging and attitude. The purpose of this research is that knowing the relation between acknowledging, attitude, and the behavior of application PPE (personal protective equipment) with the accident at the project Apartment Bekasi worker. this research is using the observational type, quantitative descriptive research design with cross-sectional oncoming. Data collection technic did by using a questionnaire sheet from a google form. The population is PT X project apartment Bekasi workers around 150 people. Sample determination in this research is using nonprobability sampling with the purposive sampling method. The result of this research shows the knowledge variable of PPE (personal protective equipment) $(P=0,051)$, attitude variable of $P P E$ (personal protective equipment) $(P=0,070)$, behavior variable of $P P E$ (personal protective equipment) $(P=0,674)$. The three variables represent that there is no significant relation with the accident at work. From the result of this research, there is a significant difference between previous research and this study, due to differences such as statistical tests, the methods used, and other supporting factors.
\end{abstract}

Keywords: Knowledge, Attitude, Behavior, The usage of PPE (personal protective equipment), Accident at work 


\section{INTRODUCTION}

Work accidents according to the Regulation of the Minister of Manpower of the Republic of Indonesia Number 07 of 2017 concerning the Social Security Program for Indonesian Workers are accidents that occur in an employment relationship, including accidents that occur on the way from home to work or vice versa (Permenaker, 2017). Two important factors cause work accidents, namely unsafe acts, and unsafe conditions. Unsafe Action is a dangerous or unsafe behavior that can cause an accident. Dangerous behavior is a failure (human failure) in following the requirements and correct work procedures, causing work accidents. Meanwhile, Unsafe conditions are conditions of a work environment that are not good or conditions of hazardous work equipment. The consequences of unsafe conditions can cause potential hazards (Kusumarini, 2017).

Data from the Employment Social Security Administering Body of the Ministry of Manpower (Kemenaker) has increased by around 5-10\% each year, so that up to 2015 there were 105,182 cases of work accidents of which 2,375 were recorded as having died and an increase of 8,966 cases in the workplace in 2018. The main cause of work accidents is still the same due to the low awareness of the importance of implementing $\mathrm{K} 3$ in industry and society. So far, the implementation of $\mathrm{K} 3$ is still considered as a cost burden, not as an investment to prevent work accidents. From the data obtained that $32 \%$ of the number of work accidents was contributed by accidents in the field of building construction (BPJS Ketenagakerjaan, 2016). Based on data from the West Java Employment BPJS, throughout 2018 the number of work accidents was 147 thousand cases. A total of 4,678 or $3.18 \%$ of them were disabled and 2,575 or $1.75 \%$ died. This data shows that every time it tends to experience movement and the incidence of work accidents is still high in the West Java area.

Factors that can cause work accidents in the construction industry such as individual factors, tools used, environment, work processes, and organization are considered as factors that influence the incidence of workaccidents. Individual factors are associated with age, work experience, and education, while organizational factors are related to workplace factors and organizational structure such as position and pressure when completing work. These two factors can directly or indirectly affect work accidents (Mohammadfam et al., 2016).

According to the Law of the Republic of Indonesia Number 13 of 2003 concerning Manpower, the government has regulated various matters for the protection of workers, including occupational safety and health. Occupational Safety and Health (K3) is a work protection effort for workers to ensure safety and health during work (Nur, 2015). Control of hazard factors carried out to minimize and even eliminate work accidents is by technical control in the form of elimination, substitution, minimization, and isolation as well as by administrative control in the form of administrative activities such as giving rewards, training, and implementing work procedures, but many companies refuse to do so. to implement these controls on the grounds of high costs. So the 
company seeks to recommend Personal Protective Equipment (PPE) as an early protection measure against the dangers of work accidents that arise in the workplace. The use of Personal Protective Equipment (PPE) is the last alternative for the company to protect its workforce from factors and potential hazards (Onni Mayendra, 2009).

Personal Protective Equipment or what is usually referred to as Personal Protective Equipment (PPE) according to the Regulation of the Minister of Manpower and Transmigration in 2010 is a tool that can protect a person whose function is to isolate part or all of the body from potential hazards in the workplace. The use of PPE is the final stage of controlling work accidents, its use will be important if the potential risk of work accidents is still relatively high even though technical and administrative controls have been carried out optimally. However, in reality, there are still many workers who do not use it even though they already know the benefits of using PPE (Rudyarti in Jatmiko, 2018).

Based on the results of research conducted (Saputro, 2015) shows that there is a relationship between knowledge and attitude where the two variables will affect the behavioral variable. Therefore knowledge and attitudes towards the use of PPE where knowledge affects a person's behavior, if the knowledge of the worker is good then the behavior of using PPE is also good and vice versa. While attitude is related to knowledge and behavior, if the attitude of the worker is good (positive) then the knowledge and behavior of using PPE is also good (positive) and vice versa (Saputro, 2015).

Meanwhile, based on the results of research from (Subing, 2018) shows that there is no relationship between knowledge and attitudes with the incidence of work accidents. Because based on a survey conducted by researchers, the condition of the workforce in the use of PPE in Hajimena housing, South Lampung has seen that head protection was replaced with ordinary cloth or hats which they often used only to protect from the sun, foot protectors only used flip-flops and did not use proper shoes. When used for work, the body armor of workers only uses clothes that they often use daily and do not use protective clothing, and do not wear eye protection, gloves, and masks. Mistakes in the use of PPE can endanger themselves and others around them (Subing, 2018).

One of the main causes of work accidents is the lack of knowledge and awareness of industry players to implement occupational safety and health (Pratiwi, 2019).

The purpose of this study was to identify the relationship between knowledge, attitudes, and behavior in the use of personal protective equipment with the incidence of work accidents in Bekasi Apartment Project construction workers.

\section{METHODS}

The research method used in this study is quantitative where quantitative methods are one type of research whose specifications are systematic, planned, and structured from the beginning to the 
making of the research design. The target population in this study were all construction workers at the Bekasi Apartment Project which amounted to about 150 people, and the sampling used nonprobability sampling with purposive sampling method, namely workers who met the inclusion criteria and exclusion criteria. The research design used for the study was observational with a cross sectional approach, namely by collecting work accident data with a questionnaire and collecting data on knowledge, attitudes, and behavior with a questionnaire and at the same time looking for a relationship between knowledge, attitudes, and behavior in using PPE with the incidence of work accidents on construction workers at Project Apartment Bekasi at one time. Data Collection Techniques in this study collected data with a questionnaire in the form of a G-form (Google Form) containing knowledge, attitudes, behavior, and workplace accidents using a questionnaire, where respondents filled out an online questionnaire.

\section{RESULTS AND DISCUSSIONS}

Based on table 1. Shows that most of the respondents have good knowledge as many as 94 people with a percentage of $97.9 \%$.

Table 1. Frequency Distribution of Respondents Based on Knowledge Variables on the Use of PPE in PT.X Project Apartment Bekasi

\begin{tabular}{|c|c|c|}
\hline Category & Frequency (f) & Percent (\%) \\
\hline Not good & 2 & 2.1 \\
\hline Well & 94 & 97.9 \\
\hline Total & 96 & 100.0 \\
\hline
\end{tabular}

Source: Primary Data, 2020

Based on table 2. Shows that most of the respondents agree with the attitude of using PPE as many as 91 people with a percentage of $94.8 \%$.

Table 2. Frequency Distribution of Respondents Based on Attitude Variables of Using PPE in PT.X Project Apartment Bekasi

\begin{tabular}{lccc}
\hline & Category & Frequency (f) & Percent (\%) \\
\hline Not agree & 5 & 5.2 \\
Agree & 91 & 94.8 \\
Total & 96 & 100.0 \\
\hline
\end{tabular}

Source: Primary Data, 2020

Based on table 3 shows that most of the respondents have positive behavior as many as 92 people with a percentage of $95.8 \%$.

Table 3. Frequency Distribution of Respondents Based on Behavioral Variables of Using Personal Protective Equipment (PPE) in PT.X Project Apartment Bekasi.

\begin{tabular}{lccc}
\hline & Category & Frequency (f) & Percent (\%) \\
\hline Negative & 4 & 4.2 \\
Positive & 92 & 95.8 \\
Total & 96 & 100.0 \\
\hline
\end{tabular}


Based on table 4. Shows that most of the respondents have positive behavior as many as 92 people with a percentage of $95.8 \%$.

Table 4. Frequency Distribution of Respondents Based on Behavioral Variables of Using Personal Protective Equipment (PPE) in PT.X Project Apartment Bekasi.

\begin{tabular}{lccc}
\hline & Category & Frequency (f) & Percent (\%) \\
Negative & 92 & 95.8 \\
Positive & 4 & 4.2 \\
Total & 96 & 100.0 \\
\hline
\end{tabular}

The relationship of Knowledge of the use of PPE with the incidence of Work Accidents in Workers at Project Apartment Bekasi.

Based on table 5 shows that of the 96 respondents who have never experienced a work accident, most of them have good knowledge of the use of PPE. The results of data analysis using the Spearman rank test resulted in p-value $=0.051>0.05$ which can be concluded that there is no significant relationship between the knowledge variable and the incidence of Work Accidents in Workers at the Bekasi Apartment Project.

Table 5. Knowledge Relationship use of Total PPE Incident on the Labor Accidents at PT.X Project Apartment Bekasi

\begin{tabular}{ccccccccc}
\hline \multirow{2}{*}{ No } & \multicolumn{3}{c}{ Work Accident Events } & \multicolumn{2}{c}{ Total } & P- \\
& Knowledge & \multicolumn{2}{c}{ Never } & \multicolumn{2}{c}{ Once } & & & \\
& & $\mathbf{n}$ & $\boldsymbol{\%}$ & $\mathbf{n}$ & $\boldsymbol{\%}$ & $\mathbf{N}$ & $\mathbf{\%}$ & \\
\hline 1 & Not Good & 2 & 100 & 0 & 0 & 2 & 100 & \multirow{2}{*}{0,051} \\
2 & Well & 90 & 95.7 & 4 & 4.3 & 94 & 100 & \\
& Total & 92 & 95.8 & 4 & 4.2 & 96 & 100 & \\
\hline
\end{tabular}

The relationship between Attitudes and Use of PPE with Work Accidents in Workers at Project Apartment Bekasi. Based on table 6 shows that 96 respondents agree with the attitude of using PPE. The results of data analysis using the Spearman rank test resulted in p-value $=0.070>0.05$ which can be concluded that there is no significant relationship between the attitude variable and the incidence of Work Accidents in Workers at the Bekasi Apartment Project.

Table 6. The Relationship between the Attitude of using PPE with the Incidence of Work Accident in Workers at PT. X Project Apartment Bekasi

\begin{tabular}{|c|c|c|c|c|c|c|c|c|}
\hline \multirow{3}{*}{ No } & \multirow{3}{*}{ Attitude } & \multicolumn{4}{|c|}{ Work Accident Events } & \multirow{2}{*}{\multicolumn{2}{|c|}{ Total }} & \multirow[b]{2}{*}{ p-value } \\
\hline & & \multicolumn{2}{|c|}{ Never } & \multicolumn{2}{|c|}{ Once } & & & \\
\hline & & $\mathbf{n}$ & $\%$ & $\mathbf{n}$ & $\%$ & $\mathbf{N}$ & $\%$ & \multirow{4}{*}{0,070} \\
\hline 1 & Not Agree & 4 & 80 & 1 & 20 & 5 & 100 & \\
\hline 2 & Agree & 88 & 96.7 & 3 & 3.3 & 91 & 100 & \\
\hline Tota & & 92 & 95.8 & 4 & 4.2 & 96 & 100 & \\
\hline
\end{tabular}


The relationship between the Behavior of the Use of PPE and the Incidence of Work Accidents in Workers at the Bekasi Apartment Project. Based on table 7 shows that 96 respondents have positive behavior towards the use of PPE. The results of data analysis using the Spearman rank test resulted in p-value $=0.674>0.05$ which can be concluded that there is no significant relationship between behavioral variables and the incidence of Work Accidents in Workers at the Bekasi Apartment Project.

Table 7. The Relationship between the Use of PPE Behavior and the Incidence of Work Accidents on Workers at PT. X Project Apartment Bekasi

\begin{tabular}{|c|c|c|c|c|c|c|c|c|c|}
\hline \multirow{3}{*}{ No } & & \multirow{3}{*}{ Behavior } & \multicolumn{4}{|c|}{$\begin{array}{l}\text { Work Accident } \\
\text { Events }\end{array}$} & \multirow{2}{*}{\multicolumn{2}{|c|}{ Total }} & \multirow{2}{*}{$\begin{array}{c}\mathrm{p}- \\
\text { value }\end{array}$} \\
\hline & & & \multicolumn{2}{|c|}{ Never } & \multicolumn{2}{|c|}{ Once } & & & \\
\hline & & & $\mathbf{n}$ & $\%$ & $\mathbf{n}$ & $\%$ & $\mathbf{n}$ & $\%$ & \multirow{4}{*}{0,674} \\
\hline 1 & Positive & & 4 & 100 & 0 & 0 & 4 & 100 & \\
\hline 2 & Negative & & 88 & 95.7 & 4 & 4.3 & 92 & 100 & \\
\hline Total & & & 92 & 95.8 & 4 & 4.2 & 96 & 100 & \\
\hline
\end{tabular}

Based on table 5 shows that the results ofthe bivariate analysis with the Spearman Rank statistical test obtained a correlation coefficient $(r=0.200)$ significant level $(p) 0.451(>0.05)$ so it can be concluded that there is no significant relationship between knowledge and the incidence of work accidents in workers at the Bekasi Apartment Project. But there is a tendency where workers do not know what should be the basis of knowledge about occupational safety and health, namely $(2.1 \%)$ compared to workers who have good knowledge (97.9\%).

The factors that cause work accidents can be sourced from tools, the environment, and humans so that these causes must be eliminated to prevent accidents. The human aspect plays an important role by $85 \%$ which causes work accidents so that these 14 aspects must be considered more important. The mechanism between knowledge and the actual occurrence of work accidents is still unclear. However, there is the possibility that knowledge can affect work accidents at any time if it is not continuously honed both from the workers and from the management of the company.

The results of this study are in line with research conducted by Deno Madasa Subing (2018) at the University Lampung, where p-value $=0.729$ means that it can be concluded that the research hypothesis is rejected or there is no significant relationship between knowledge and the incidence of work accidents. However, this study is not in line with the research conducted by Vondra Anggi Saputro (2015) it was found that there is a p-value $=0.002$ which is based on the Spearman rank test with a degree of significance of $0.05 \%$, the p-value is obtained, which means it can be concluded that there is a relationship between knowledge of workplace accidents. So from the two studies, there are two different conclusions because the sampling method and the number of samples studied are 
different. In the study (Saputro, 2015) is said to be the relationship between knowledge and attitudes with the incidence of occupational accidents due to both these variables supported by factors such as age, education, and working lives so that the chances of $\mathrm{H} 1$ is accepted or otherwise significant relationship. It is different from research (Subing, 2018) which concludes that there is no significant relationship between knowledge, attitudes, and behavior with the incidence of work accidents because of the absence of supporting factors. So in this study, it was concluded that the absence of a relationship between the three variables, namely knowledge, attitudes, and behavior with the incidence of work accidents, could be due to the existing population and samples, the sampling method, or the presence or absence of identified supporting factors.

The absence of a relationship between knowledge and the incidence of work accidents can be due to the heterogeneous sample population, differences in criteria, differences in statistical test methods, and a large number of respondents. The target the population is heterogeneous because the population comes from different levels of education.

Based on table 6 shows that the results of the bivariate analysis with the Spearman Rank statistical test obtained a correlation coefficient $(r=0.186)$ significant level $(p) 0.070(>0.05)$ so it can be concluded that there is no significant relationship between attitudes and the incidence of work

accidents at workers at the Bekasi Apartment Project. But there is a tendency where the attitude of workers who are sometimes reluctant to agree with what has been set by the company management but even so not a few workers agree with what is set by the company management for their safety (94.8\%) compared to workers who do not agree with it, which is only around (5.2\%).

Glendon and Eugene suggest that some individuals will accept danger as a risk and try to avoid it, some other individuals will recognize the risk but perceive it as a challenge. This perception can lead to unsafe actions in the face of danger and increase the likelihood of someone getting into an accident. However, there is a possibility that a person's attitude can at any time affect work accidents if it is not continuously honed with training or reprimands from fellow workers and the company management.

The results of this study are in line with research conducted by Deno Madasa Subing (2018) at the University of Lampung, the p-value $=0.393$, meaning that it can be concluded that the research hypothesis is rejected or there is no significant relationship between knowledge and the incidence of work accidents. However, this study is not in line with the research conducted by Vondra Anggi Saputro (2015) it was found that there is a p-value $=0.005$ which is based on the Spearman rank test with a degree of significance of $0.05 \%$, the p-value is obtained, which means it can be concluded that there is a relationship between knowledge of accidents. So from the two studies, there are two different conclusions because The sampling method and the number of samples studied are different. In the study (Saputro, 2015) is said to be the relationship between knowledge and attitudes 
with the incidence of occupational accidents due to both these variables supported by factors such as age, education, and working lives so that the chances of $\mathrm{H}_{1}$ is accepted or otherwise significant relationship. It is different from research (Subing, 2018) which concludes that there is no significant relationship between knowledge, attitudes, and behavior with the incidence of work accidents because of the absence of supporting factors.

So in this study, it was concluded that the absence of a relationship between the three variables, namely knowledge, attitudes, and behavior with the incidence of work accidents, could be due to the existing population and samples, the sampling method, or the presence or absence of identified supporting factors.

The absence of a relationship between attitudes and the incidence of work accidents can be due to the heterogeneous sample population, differences in criteria, ifferences in statistical test methods, and the large number of respondents. The target population is heterogeneous because the population comes from different ways of thinking and lifestyle.

Based on table 7 shows that the results of the bivariate analysis with the Spearman Rank statistical test obtained a correlation coefficient $(r=0.043)$ significant level (p) $0.674(>0.05)$ so it can be concluded that there is no significant relationship between behavior and the incidence of work accidents at workers at the Bekasi Apartment Project. But there is a tendency where the behavior of workers who show a negative attitude or refuse to apply what is appropriate in terms of implementing $\mathrm{K} 3$ should be the company's attention even though it is only (4.2\%) compared to workers who are positive or widely accept to implement what is required. has been determined by the company that is $(95.8 \%)$.

According to Kwick, behavior is an action or behavior of a person that can be observed and even learned, but there is a the possibility that a person's behavior can affect work accidents at any time if it is not continuously honed with strict application from fellow workers and the company management.

The results of this study are not in line with research conducted by Deno Madesa Subing (2018), it was found that there is a p-value $=0.03$ which is based on statistical tests with a degree of significance of $0.05 \%$, the p-value is obtained, which means it can be concluded that there is a relationship between between knowledge and the incidence of work accidents.

In this study, the researcher concluded that there was no relationship between the behavior of using PPE and the incidence of accidents because according to (Saputro, 2015) the knowledge and attitude variables will affect the behavioral variables, where knowledge affects a person's behavior, if the knowledge of the worker is good then the behavior of using PPE is also good and otherwise. While attitude is related to knowledge and behavior, if the attitude of the worker is good (positive) then the knowledge and behavior of using PPE are also good (positive) and vice versa. 
The absence of a relationship between attitudes and the incidence of work accidents can be due to the heterogeneous sample population, different criteria, differences in statistical test methods, and the large number of respondents. The target population is heterogeneous because the population comes from activities outside and within the project.

\section{CONCLUSION}

1. Most of the workers at PT. X Project Apartment Bekasi has good knowledge of 94 people $(97.9 \%)$. Because workers know what are the risk factors that can cause work accidents.

2. Most of the workers at PT. X Project Apartment Bekasi has an agreeable attitude of 91 people $(94.8 \%)$. Because workers have the willingness to apply PPE according to their needs.

3. 3. Most of the workers at PT. X Project Apartment Bekasi showed positive behavior as many as 92 people (95.8\%). Because workers show positive actions on the use of PPE in the work environment.

4. 4. S ost workers at PT. X Project Apartment Bekasi has never experienced a work accident as many as 92 people $(95.8 \%)$. Because workers have never had a work accident with the support of the previous 3 variables,

5. 5. Based on the research that not there is a relationship between the incidence of occupational accidents knowledge workers in the Bekasi Apartment Project is intended to result from pvalue 0.451 (> 0.05), because workers have good knowledge of the importance of applying PPE with the incidence of work accidents.

6. 6. Based on the results of the study that there is no relationship between attitudes and the incidence of work accidents at the Bekasi Apartment Project, it is indicated by the results of p-value 0.070 (> 0.05 ), because workers have a good willingness to the importance of applying PPE with the incidence of work accidents.

7. 7. Based on the results of the study that there is no relationship between attitudes and the incidence of work accidents at the Bekasi Apartment Project, it is indicated by the results of p-value 0.674 (> 0.05 ), because workers have a positive action on the importance of applying PPE with the incidence of work accidents.

\section{THANKYOU-NOTE}

The best gratitude goes to Dr. Dewi Purnamawati, S.KM., M.KM as Advisor for her continuous guidance and direction so that this article can be accomplished properly.

\section{REFERENCES}


Barizqi, I. N. (2015). Hubungan Antara Kepatuhan Penggunaan APD Dengan Kejadian Kecelakaan Kerja Pada Pekerja Bangunan PT. Adhi Karya Tbk Proyek Rumah Sakit Telogorejo Semarang (Doctoral dissertation, Universitas Negeri Semarang).

Endroyo, B., \& Tugino, T. (2009). Analisis faktor-faktor penyebab kecelakaan kerja konstruksi. Jurnal Teknik Sipil dan Perencanaan, 9(1), pp-21.

Indragiri, S., \& Salihah, L. (2019). HUBUNGAN PENGAWASAN DAN KELENGKAPAN ALAT PELINDUNG DIRI DENGAN TINGKAT KEPATUHAN PENGGUNAAN ALAT PELINDUNG DIRI. Jurnal Kesehatan, 10(1), 1238-1245.

JATMIKO, Jatmiko. PENGARUH PENGETAHUAN TENTANG PENGETHAUAN ALAT PELINDUNG DIRI (APD) TERHADAP KEPATUHAN PENGGUNAANYA OLEH KARYAWAN PRODUKSI BETA LACTAM 2 DI PT. X. 2018. PhD Thesis. AKFAR PIM. Kemnaker.go.id (2020, 14 Februari). Jadikan K3 sebagai prioritas dalam bekerja. Diakses 11 April 2020, dari https://kemnaker.go.id/news/det ail/menaker-jadikan-k3-

sebagai-prioritas-dalam-bekerja

Kusumarini, D. A. (2017). Perbedaan Unsafe Action dan Unsafe Condition antara Sebelum dan Sesudah Safety Patrol (Studi di PT Mekar Armada Jaya Magelang) (Doctoral dissertation, UNIMUS).

La Tho, I., R. (2020). ANALISIS PENGAWASAN PETUGAS SAFETY DENGAN KEPATUHAN PENGGUNAAN ALAT PELINDUNG DIRI (APD) DI PROYEK PEMBANGUNAN APARTEMAN MARIGOLD AT NAVA PARK. JITMI (Jurnal Ilmiah Teknik dan Manajemen Industri), 2(2), 98-105.

Laksono, B. B. B. (2018). Hubungan Pengetahuan APD, Masa Kerja dan Ketersediaan APD dengan Kepatuhan Pemakaian APD Pekerja Bagian Spinning PT. Kusumaputra Santosa.

Lionindonesia.org (2019, 20 April). Kasus Kecelakaan Kerja Di 2018. Diakses 10 April 2020, dari http://lionindonesia.org/blog/2019/04/20/157-313-kasus- kecelakaan-kerja-di-2018-iloingin-peningkatan-kondisi- $\quad$ kerja/\#: :text=ILO\%20belum\%20lama\%20ini\%20memperkira kan,tahun\%20akibat\%20kecela kaan\%20terkait\%20kerja.

Peraturan Menteri Ketenagakerjaan RI.2017. Program Jaminan SosialTenaga Kerja Indonesia nomor 07 Tahun 2017 [diunduh 10 April 2020]. Tersedia dari https://www.bpjsketenagakerjaa n.go.id/assets/uploads/peraturan/07082017_141856_Permen_Ketenagakerjaan_RI_7_2017.pd $\mathrm{f}$

Pratiwi, O. R., \& Hidayat, S. (2014). Analisis Faktor Karakteristik Individu Yang Berhubungan dengan Tindakan Tidak Aman Pada Tenaga Kerja di Perusahaan Konstruksi Baja. The Indonesian Journal of Occupational Safety and Health, 3(2), 182-191. 
Pratiwi, W. I. (2019). HUBUNGAN PENGETAHUAN, SIKAP, DAN PERILAKU PENGGUNAAN ALAT PELINDUNG MATA DENGAN RIWAYAT KEJADIAN TRAUMA MATA SERPIHAN BESI PADA PEKERJA LAS DI KAWASAN INDUSTRI PULOGADUNG TAHUN 2018 (Doctoral dissertation, Universitas Pembangunan Nasional Veteran Jakarta).

Rahmadina, H. (2015). Perbedaan Perilaku Agresi Remaja Berdasarkan gender Yang Tinggal Dengan Orangtua Tunggal DI Kota Sukabumi (Doctoral dissertation, Universitas Pendidikan Indonesia).

Rinawati, S., Maharani, R. A., \& Wijayanti, R. (2017). OCCUPATIONAL SAFETY AND HEALTH INSPECTION PROGRAM ACHIEVEMENT OF SAFETY CULTURE IN NOODLES INDUSTRY PT ABC SEMARANG. Journal of Industrial Hygiene and Occupational Health, 2(1), 75-96.

RIYANTO, Budiman. Kapita selekta kuesioner pengetahuan dan sikap dalam penelitian kesehatan. Jakarta: Salemba Medika, 2013, 66-69.

Rosalin, H. (2016). Analisis Risiko Kecelakaan Kerja Dengan Metode Fault Tree Analysis (FTA).

Saputro, V. A. (2015). Hubungan Antara Pengetahuan dan Sikap Dengan Penggunaan Alat Pelindung Diri (APD) Pada Pekerja Di Unit Kerja Produksi Pengecoran Logam (Doctoral dissertation, UNIVERSITAS MUHAMMADIYAH SURAKARTA).

Simamora, S. K. (2015). HUBUNGAN PENGETAHUAN, SIKAP DAN PERILAKU GIZI IBU DENGAN STATUS GIZI BATITA DI KECAMATAN BANJAR AGUNG KABUPATEN TULANG BAWANG (Doctoral dissertation, Fakultas Kedokteran).

Siregar, D. I. S. (2014). Faktor-Faktor Yang Berhubungan Dengan Kecelakaan Ringan Di Pt Aqua Golden Missisippi Bekasi Tahun 2014.

SUBING, D. M. (2018). HUBUNGAN PENGETAHUAN, SIKAP, DAN PERILAKU PENGGUNAAN ALAT PELINDUNG DIRI DENGAN KEJADIAN KECELAKAAN KERJA PADA TENAGA KERJA BANGUNAN DI PERUMAHAN HAJIMENA LAMPUNG SELATAN.

Tarwaka, P. Sc. M. Erg. 2008. Keselamatan dan Kesehatan Kerja Manajemen dan Implementasi K3 di Tempat Kerja.

Wirdati, I. E., Denny, H. M., \& Kurniawan, B. (2017). Analisis Faktor-faktor Yang Mempengaruhi Kecelakaan Kerja Pada Pekerja Maintenance Elektrikal Dalam Menerapkan Work Permit Di PT. X Semarang. Jurnal Kesehatan Masyarakat (e-Journal), 3(3), 456-464.

Wirdati, I. E., Denny, H. M., \& Kurniawan, B. (2017). Analisis Faktor-faktor Yang Mempengaruhi Kecelakaan Kerja Pada Pekerja Maintenance Elektrikal Dalam Menerapkan Work Permit Di PT. X Semarang. Jurnal Kesehatan Masyarakat (e-Journal), 3(3),456-464. 
Yenni, M., \& Darmawan, E. S. (2020). Faktor Yang Mempengaruhi Pekerja Dalam Pemakaian Alat Pelindung Diri Pada PT. X. Jurnal Endurance, 5(1), 1-6. 